\title{
Interactions between Economic Growth, Financial Development, and Income Inequality in General and in China
}

\author{
Samuel M. Jung ${ }^{1}$ \\ ${ }^{1}$ State University of New York at Cortland, United States \\ Correspondence: Samuel M. Jung, Department of Economics, 32 Graham Avenue, Cortland, NY, 13045 USA, \\ Tel: 607-753-2570. E-mail: Samuel.jung@ cortland.edu
}

Received: February 13, 2021

Accepted: March 19, 2021

Online Published: April 10, 2021

doi:10.5539/ijef.v13n5p67

URL: https://doi.org/10.5539/ijef.v13n5p67

\begin{abstract}
This paper is a survey of the literature on the theoretical and empirical interactions among financial development, economic growth, and income inequality. Prevailing evidence on finance and economic growth suggests that financial intermediaries' development significantly helps to enhance economic growth. In addition, previous studies show that financial development plays an important role in reducing income inequality. Empirical research on a Chinese case, however, shows varied empirical findings or no clear association between financial development and income inequality.
\end{abstract}

Keywords: economic growth, financial development, inequality

JEL classification: E01, E44, J31, O11, O47, O16.

\section{Introduction}

Empirical and theoretical studies on the causal effects among economic growth, financial development, and inequality have increased over the last few decades. This is not surprising, as economic growth is accompanied by financial development. Although financial development has a favorable function of promoting economic growth, it can bring a dysfunction of increasing income inequality. In other words, development in the financial sector affects investment in human capital and/or physical capital. Thus, by influencing capital allocation, financial development can change the aggregate output (which is analogous to economic growth) and the unemployment rate, with potential implications on poverty and income distribution.

The literature indicates a positive relationship between financial development and economic growth, but the relationship between financial development and inequality remains unclear, both theoretically and empirically. For example, the theoretical framework suggested by Greenwood and Jovanovic (1990) used a theoretical endogenous growth model and provided an inverted U-shaped hypothesis between financial development and inequality while Galor and Zeira (1993) provided a linear hypothesis.

The empirical evidence is also controversial. Liang (2006) found that financial development tends to alleviate unequal income distribution of the urban-rural divide in China. According to Xie and Zhou (2014), however, income inequality, measured by the Gini coefficient, steadily increased from 0.30 to 0.55 from 1980 to 2012 despite improved financial markets in China. In addition, the Gini coefficient for Shanghai, a major city in China and the $8^{\text {th }}$ largest city in the world, increased from 0.244 to 0.389 . The Gini coefficient for Chongqing, a major city in southwest China and one of five national central cities in China, increased from 0.40 to 0.48 , which is much higher than 0.311 (Note 1), the average Gini coefficient for OECD countries.

Just as Chinese economic reform is in the spotlight due to its impact on economic growth, China's continuous reforms have affected the depth of its financial sector's development and innovation since the late 1970s. As a first step to reform, the Chinese government abolished a central banking system and set up a two-tiered banking system. When the People's Bank of China was designated as the Chinese central bank in the mid-1980s, several types of financial institutions formed, such as policy banks, equitized banks, city commercial banks, rural commercial banks, joint-stock commercial banks, and foreign banks (Note 2).

The Chinese financial system depends on its banking system, even though stock markets in China have developed quickly since the 1990s and total market capitalization in the Chinese stock exchange ranks fourth in the world. China also has the second largest stock market in Asia. On the other hand, in terms of the financial 
sector's size, banks in China are larger than the stock market. Table 1 shows that, after economic reform, financial sectors in China have developed rapidly: the ratio of the money supply (M2) to real gross domestic product (GDP) surged from 0.99 in 1995 to 1.91 in 2014, the ratio of total deposits to real GDP increased from 0.88 in 1995 to 1.77 in 2014, and the ratio of total loans to real GDP increased from 0.82 in 1995 to 1.27 in 2014 .

Interestingly, China, the world's fastest growing economy, achieved phenomenal growth, became the engine of global economic growth through stepwise economic reforms and financial development, and reduced the number of people living below the poverty line. Recently, however, against all expectations, the Gini coefficient of each province in China sharply increased, which is an unpleasant scenario for economic growth, financial development, and income inequality.

Table 1. Recent trend of financial development in China: 1995-2014

\begin{tabular}{lccc}
\hline & M2/ GDP & Deposits / GDP & Loans / GDP \\
\hline 1995 & 0.99 & 0.88 & 0.82 \\
1996 & 1.05 & 0.96 & 0.94 \\
1997 & 1.14 & 1.03 & 1.02 \\
1998 & 1.22 & 1.12 & 1.04 \\
1999 & 1.32 & 1.20 & 0.99 \\
2000 & 1.34 & 1.23 & 1.01 \\
2001 & 1.42 & 1.30 & 1.08 \\
2002 & 1.51 & 1.40 & 1.16 \\
2003 & 1.61 & 1.51 & 1.10 \\
2004 & 1.57 & 1.49 & 1.04 \\
2005 & 1.59 & 1.53 & 1.03 \\
2006 & 1.57 & 1.53 & 0.97 \\
2007 & 1.49 & 1.44 & 0.95 \\
2008 & 1.49 & 1.46 & 1.14 \\
2009 & 1.75 & 1.71 & 1.16 \\
2010 & 1.76 & 1.74 & 1.12 \\
2011 & 1.74 & 1.65 & 1.17 \\
2012 & 1.80 & 1.70 & 1.21 \\
2013 & 1.86 & 1.75 & 1.27 \\
2014 & 1.91 & 1.77 & \\
\hline
\end{tabular}

Source: Chinese Statistical Yearbooks.

Early literature focused on the association between economic growth and inequality (i.e., Chen, 1996; Kuznets, 1955; Lardy, 1978, 1980; Lyons, 1991; Oi, 1993; Oshima, 1992; Sloan, 1994; Williamson, 1965; Yang, 1996) and on the relationship between financial development and economic growth. As world financial markets continue to grow rapidly, there is greater importance on the impacts of financial development. Thus, topics extended to the relationship between financial development and economic growth (Boyreau-Debray, 2003; Zhang et al., 2012). In addition, issues on economic growth, financial development, and inequality continue to concentrate on the relationship between financial development and inequality (i.e., Atkinson \& Brandolini, 2001; Banerjee \& Newman, 1993; Beck, Demirgüç-Kunt, \& Levine, 2004; Clarke, Xu, \& Zou, 2003; Galor \& Zeira, 1993; Greenwood \& Jovanovic, 1990; Liang, 2006; Li, Squire, \& Zou, 1998; Qi , Ran, Mingxing, \& Chen, 2003; Tsui, 1993; Wei \& Wang, 1997; Wei \& Wu, 2001).

With increasing interest in income inequality, Atkinson and Brandolini (2001) questioned potential problems from the use of a secondary dataset. A potential problem in using secondary datasets is inconsistency in the definition. Another possible problem in using Gini coefficients for cross-country analysis is the use of different source data. For example, when we calculate a Gini coefficient, the primary source of data is from a national household survey. However, other administrative data can be used as well, so the data source for calculating a Gini coefficient can differ.

In this paper, I describe various literature on economic growth, financial development, and inequality, including theoretical and empirical studies, using a cross-country analysis and a Chinese sample. The paper is organized as follows. Section 2 reviews the relationship between economic growth and income inequality in China, including a theoretical framework and empirical evidence. Section 3 describes the relationship between financial 
development and economic growth in China. Lastly, Section 4 reviews a theoretical framework and empirical evidence on financial development and inequality in China.

\section{Economic Growth and Inequality}

The theoretical studies, empirical works, and political worries about the course of income inequality as the product of economic growth have brought the causal link between economic growth and income inequality to the forefront. In the following, I review literature on economic growth and inequalities and then describe empirical evidence using a cross-country analysis and a Chinese case.

\subsection{Early Theoretical Framework on Economic Growth and Income Inequality}

Much theoretical and empirical research on economic growth and income inequality has its roots in the classical contributions of Kuznets (1955). He created a theoretical framework to hypothesize that economic growth is linked to inequality in an inverted U-shaped pattern, where income inequality widens at the first stage of development and then is reduced at the later stage of development.

In the early stages of an industrial revolution, a country experiences urbanization, where cities are the center of the country's economy. As former workers in rural areas migrate to the city for high paying jobs in an industrialized urban area, the income disparities between urban and rural areas increase. When income per capita approaches a certain point, income disparities between urban and rural areas are expected to be lower due to the emergence of a new industrial system, such as free market economy, which facilitates additional rapid economic growth. Therefore, Kuznets suggested that the level of income inequality can be explained by an inverted U-shaped curve since the level of income inequality increases in the early phases of economic growth, like low-income countries or developing countries. After achieving a certain point, the level of income inequality decreases again in later phases of economic growth, like high-income countries or developed countries.

In a simple model, Vijverberg (1991) examined the contributing factors to inequality in a growing economy. Using the model, the author attempted to analyze why some countries experienced higher income inequality during the growth process while other countries mingled fast economic growth with a good record of income distribution. Under a monotonic saving rule (i.e., a family that owns more capital saves at least as much as a family that owns less capital), the conflict between equity and growth (i.e., higher inequality and higher growth) is not due to "wealthy families save more." Rather, the conflict is caused by the condition that the inequality of saving is strictly greater than the inequality of capital ownership. The conditions for an economy to be in conflict and/or non-conflict regimes were analyzed in detail. Under a non-monotonic saving rule, Vijverberg (1996) incorporated social class mobility and macroeconomic conditions in the conflict/non-conflict analysis of equity and growth.

Barrios and Strobl (2009) suggested a theoretical model to analyze the dynamics of regional growth. Once a technological innovation takes place in a specific region, this region receives the benefits of a high rate of growth at the initial stage of economic growth. Other regions catch up to this leading region with a lag, and the length of this lag depends on differing technological capabilities. Thus, regional inequalities increase at the first stage of technological innovation and later decrease after achieving the peak of regional inequalities. This is because lagging regions adopting technological innovation will develop at the same rate as those of the leading region and then will have additional growth impact from the natural rate of convergence. This model suggests an inverted U-shaped hypothesis in the short run, while Kuznets' hypothesis focuses on long-run structural changes.

Turnovsky (2015) developed a model to investigate the association between economic growth and income inequality focusing on public investment as a key determinant of the association. He suggested a general equilibrium growth model with heterogeneous agents, which is characterized by homogeneity of the utility function and the same unrestricted access to perfect factor markets for all agents. In this model, government investment promotes the productivity of private capital, encouraging its accumulation. Under the unequal distribution of private capital among agents, government investment increases wealth inequality over time.

\subsection{Empirical Evidence on Economic Growth and Income Inequality}

First, I describe literature on the relationship between income inequality and economic growth for developed or developing countries using a cross-country analysis. Next, I describe the relationship between economic growth and income inequality in China.

Williamson (1965) depicted patterns of regional inequalities under the process of national development using examples of the U.S., France, Italy, Spain, Germany, Canada, Brazil, Sweden, Australia, Norway, and India by focusing on a new popular phenomenon of regional income inequality known as the North and South Problem, which illustrates the absolute differential between rich and poor areas. The cross-country analysis found that 
economic development and regional inequality have the following pattern. As the national economy grows and expands, the degree of regional inequality narrows. Among the countries in the sample, Spain, Italy, Columbia, and Brazil, nations below the middle-income class, did not generate the expected conclusion that lower income per capita is associated with greater income inequality. U.S. data, however, generated what was expected - the lower income per capita, the greater income inequality. In addition, data on Germany, Sweden, France, and Canada showed that regional inequality widened substantially at an early stage of economic development, while regional inequality was reduced as the national economy matured. In conclusion, the gap between the rich and the poor is deeper in the agricultural sector than in the industrial sector.

In another influential study, Ahluwalia (1976) studied the relationship between economic growth and income inequality using a cross sectional data set of 14 developed countries, 40 developing countries, and six socialist countries, creating a multivariate regression model to examine the cross-country association between development process and income inequality. The empirical results strongly support the hypothesis that income inequality widens at the beginning of economic development and then decreases in the later stages of economic development. Second, the average real income of the lower percentile group increased as the gross national product (GNP) per capita increased, even though the speed of increasing real income for the lower percentile groups was more gradual than for the upper income groups. Finally, the findings do not support the view that higher income inequality is related to faster economic growth.

Oshima (1992) discussed Asian income distribution trends in relation to the inverted U-shaped curve. The Asian income distribution trends corresponded to the inverted $U$ curve; however, the peak of the Asian income distribution trends differed from Western countries except for Japan, whose income inequality trends are similar to the trends of Western countries. More specifically, the peak of Asian income inequality trends was achieved earlier in the course of development growth than those in Western countries. While the Gini coefficient of Western countries decreased in the 1920s when income per capita exceeded \$2,000, the peak Gini coefficient of Asian countries was reached when income per capita exceeded $\$ 1,000$. This is because Asian countries are aligned to the agricultural sector, while Western countries are aligned to the industrial sector.

Although there is no strong supportive evidence that economic growth influences income inequality, Psacharopoulos et al. (1995) looked at how a period of recession during the 1980s affected income inequality of 18 Latin American countries. Unlike Kuznets' (1955) inverted U-shaped curve for a long-run relationship, the authors investigated short-run cyclical behavior between growth and inequality based on micro data obtained from household surveys. The reduction in economic growth widened income inequality among the Latin American countries and an increase in economic growth decreased income inequality measured by the Gini coefficient and the share of wealth of the bottom 20th percentile. Since economic crisis exerts downward pressure on wages and employment, employees were forced to agree to wage deductions or become unemployed and, therefore, income inequality deteriorated.

In another cross-country analysis on economic growth and income distribution, Ravallion and Chen (1997) researched the empirical link between economic growth and income inequality using a data set of 67 developing countries from 1981 to 1994 . To provide alternative measures of distribution and poverty, the authors analyzed the relationship of poverty changes with economic growth. They found that higher growth rates tended to reduce the rates of poverty over the between 1981 and 1994. Overall, for the whole sample, the increase in average consumption was connected to reduced income inequality. However, when data from Central Asia and Eastern Europe were excluded, income inequality tended to widen. This empirical finding is not robust since the negative coefficients of the economic growth measures were insignificant. In addition, the authors found that income inequality was not associated with average consumption growth when omitting Eastern European and Central Asian countries. They found that growth in average living standards was strongly associated with the rates of absolute poverty reduction.

Scully (2002) researched the association between economic growth and inequality using a cross-country dataset of developed and developing countries in Asia for 1975, 1980, 1985, and 1990. A main finding is that in a regression equation that explain the Gini coefficient (a measure of income inequality), the slope of the degree of economic freedom is negatively significant, suggesting that more economic freedom, a measure of the role of government policy in stimulating economic development and in reducing income inequality, is associated with a decrease in income inequality. Also, the estimate of the effect of economic growth on inequality was negative and statistically significant, which means income distribution equalized as the economy grew and expanded. In conclusion, a higher degree of economic freedom resulted in more equal income distribution, and economic growth improved income disparity. 
However, Atkinson and Brandolini (2001) and Clarke et al. (2003) exposed potential problems in the comparative analysis using cross-country data, stating that secondary cross-country data has problematic issues related to data quality and data consistency. These potential problems will be discussed later in detail. Instead of using a cross-sectional dataset, Krongkaew and Kakwani (2003) analyzed how economic growth affects income inequality in Thailand, one of the fastest developing countries in Asia, using a dataset between 1962 and 2000. They found that the number of people under the poverty line decreased as GDP increased due to the increase on the growth rate of GDP, but Thai people's income distribution became less equal. According to these findings, the association between economic growth and income inequality conforms to the Kuznets curve, which indicates an increase in inequality as starting from a lower level of development. In addition, the authors found that the impact of economic growth on poverty reduction is offset by a high degree of unequal income distribution.

Recently, Fawaz et al. (2014) examined the effect of income disparities on economic growth applying system GMM (Generalized Method of Moments) based on World Bank classifications (56 countries classified as high-income developing countries and 55 countries classified as low-income developing countries) from 1960 to 2010. Their findings revealed that income inequality is positively associated with economic growth measured by per capita GNP in high-income developing countries, while income inequality is negatively related to economic growth in low-income developing countries.

\subsection{Economic Growth and Income Inequality in China}

Lardy (1978) examined how the Chinese government regulated resource allocation, the relationship between these government policies and the pattern of economic growth, and the association between these policies and income distribution in China. The paper described the adoption of the Soviet model of planning, which is about the extension of central control to functional areas in the Chinese economy. This intensively centralized system was quite successful in inducing investment and accelerating economic growth in China. However, these radical policies for a vertical relationship between economic planning and management severed developmental relations among local governments that had no economic cooperation in their provinces. A centralized system on decisions resulted in inefficiency as well. In addition, although a causal relationship between economic growth and the rise of income inequality was not completely discovered, the paper found that planned economic control can mitigate the negative distributive outcomes of economic growth.

\subsubsection{Economic Growth and Income Inequality at the Urban-Rural Level}

The central government set in motion many transitional measures that positively influenced the economic welfare of Chinese rural areas (Oi, 1993). While people in rural areas improved their income, the income gap between urban and rural was extraordinarily high in China compared to other developing countries in Asia between 1978 and 1990. According to the paper, the main source of income inequality in China came from the gap between the urban and rural income during this time. Examples of the central government's policies include revising urban-biased pricing for grain under the procurement plan and relaxing of the rural economy structure permitting people in rural areas to diversify to more profitable grain and involving the industrial sector rather than the agricultural sector. These reforms were not considered persistent shifts to a rural bias reform, and economic development of rural areas in China was not the fruit of urban or rural bias but the result of local governments' efforts.

Yang and Wei (1996) summarized several key factors that led governors to rethink regional inequalities and key policies, such as credit availability, tax incentives, and interregional cooperation, to decrease income disparities. The income gap between rural and urban areas in China doubled between 1965 and 1992. Since the State Council decided to stimulate rural enterprise development in order to reduce rural-urban income gaps, several forms of government policy remarkably preceded rural enterprises' development. Many local governments and enterprises accepted and instantly applied the central government's policies, which favored rural enterprises' interests. However, the central government's effort to decrease regional inequality did not properly reduce the gap between the coast region and the inland area. Chinese leadership recognized the economic gap between urban and rural areas, resulting in a session of the National People's Congress in 1995 that emphasized economic development policies of inland regions and ethnic areas, such as intergovernmental fiscal transfers and foreign investment.

\subsubsection{Economic Growth and Income Inequality at the Province Level}

Unlike previous research on economic growth and income inequality at the urban and rural level, Lyons (1991) re-examined the Chinese model of development in terms of provincial growth and income inequality at the province level. New provincial income data released by the State Statistical Bureau in China from 1952 to 1987 and the coefficient of variation, a measure of income inequality, were utilized for the analysis of economic 
growth and income inequality. The author summarized the dispersions of each measure, net material product as an output measure and the coefficient of variation as a measure of inequality, to look into within provincial level disparities. First, the analysis on output data captured provincial disparities at the initial stage of development. Based on the analysis of dispersion, overall growth rates and industrialization rates are quite different among provinces, and the evidence related to consumption shows a solid trend toward narrowing inequality across the Chinese provinces in terms of relative distribution. Disparities in growth rates in consumption are similarly compressed by transfers among provinces and by separating consumption from output in non-agriculture. In sum, the author argued that interprovincial inequality has narrowed since 1983.

Chen and Fleisher (1996) examined the relationship between regional inequality and Chinese economic growth by focusing on the impact of the growth process during the post-Mao transformation period on provincial inequality. Based on panel data between 1978, the beginning of the economic reform, and 1993, they saw that overall provincial inequality measured by the coefficient of variation narrowed but that the inequality between coastal and non-coastal regions increased somewhat. This is mainly because government encouragement and private investment incentives created a significant income gap among provinces in China.

\section{Financial Development and Economic Growth}

\subsection{Characteristics of Financial Development in China}

A developed financial system facilitates transactions, mobilizes savings, allocates these funds to economic activities, and supervises the activities of the recipients of those funds. A well-developed financial system accompanying these roles enhances economic growth (Levine, 1997). On the other hand, an underdeveloped financial system leads to as misallocated credit, misplaced loans, and poorly managed borrowers, which may harm economic growth (Calomiris \& Hubbard, 1990).

China's economy has grown tremendously since its initial economic transition in 1978. China has now become part of the Group of Two (G2) (Note 3) along with the United States as the two most influential and powerful countries. According to Allen et al. (2005), there is a high probability that China will be the world's largest economy within 10 years based on purchasing power parity (PPP). As is well known, China's tremendous growth has been accompanied by its financial development. That being so, Allen et al. (2005) argued that China is a counterexample to the conventional relationship between finance and economic growth.

China's banking system transition was initiated in the early 1980s. The four state-owned specialized banks, called as The Big Four, began to accept deposits and engaged in banking activities in the 1980s. Even as the Big Four converted to publicly-listed banks and as more domestic/foreign banks joined the system, the Chinese government still has a dominant impact on banks' activities. While China has experienced a huge transformation in the financial sector, the four major state-owned banks possess over $60 \%$ of the total financial assets in China.

However, the banking sector's efficiency is poor since it is dominated by four large state-owned banks. In 1978, China separated the People's Bank of China from the Ministry of Finance. Then in 1979, the Chinese government re-founded the Bank of China, the People's Construction Bank of China, and the Agricultural Bank of China so they might compete for lending services and savers. In 1983, the People's Bank of China was designated as the central bank. In addition, the Industrial and Commercial Bank was founded to provide more financial services. It is now the largest bank in China with half of all bank lending. Additionally, three smaller national banks (Everbright, Hua Xia, and Min Sheng) entered the Chinese banking sector and a number of regional banks opened in 1987 and 1988. Different types of non-bank financial service providers, such as trust and investment firms; urban credit cooperatives; and financial service companies that provided securities, credit rating, and financial leasing services, were established in the mid-1980s. The Chinese government generated a variety of structural changes in the financial system, but policy loans (Note 4) are the prominent characteristic of its financial structure. In fact, by the end of 1991, policy loans made up $67 \%$ of Bank of China's assets, $51.2 \%$ of Agricultural Bank's assets, $58 \%$ of the Construction Bank's assets, and $25 \%$ of Industrial and Commercial Bank's assets (Cull \& Xu, 2000). Lastly, an important point of Chinese financial structures is that $25 \%$ of state owned enterprises' (SOE) loans depended on direct government transfers in the early 1980s. This decreased to about $2 \%$ between 1990 and 1994. In contrast, the proportion of bank finance not dependent on government transfers increased from $15 \%$ to $32 \%$ between 1980 and 1987.

Cull and Xu (2003) analyzed the link between bank finance and state-owned enterprises' productivity in China from 1980 to 1994 . Using a probit model where the dependent variable is access to finance and a tobit model where the dependent variable is the share of total finance, Cull and Xu (2003) found that bank finance is positively correlated with SOEs' profitability. Its positive association between bank finance and profitability was stronger in the 1980s. However, in the 1990s, the positive association between bank finance and SOEs' 
profitability weakened since the responsibility for SOE bailout moved from the government to banks. Additionally, the authors did not find any strong association between direct government transfers and SOEs' profitability in the 1980s and 1990s.

A second stage of financial reforms in China occurred between 1994 and 2000. Initially, three policy banks for policy lending were founded in 1994 and the central bank adopted indirect monetary control. Later, in 1995 the central bank enacted the Commercial Bank of Law of China to establish pivotal elements for the operation of commercial banks. In 1998, the Chinese government ceased credit planning for state-owned commercial banks. Lastly, in the late 1990s the Chinese government restructured state-owned commercial banks and founded four Asset Management Companies using 270 billion Yuan of government money. Notably, in 1996 the first private-owned bank, China Minsheng Bank Corporation, was founded and 13 national joint-equity commercial banks were established by the beginning of 2000 .

Since China's entrance into the World Trade Organization (WTO) in December, 2001, China has taken more active policies such as liberalization of the interest rate, relaxation of regulations on foreign banks, and mitigation of restrictions on ownership takeovers to encourage non-state financial intermediaries along with more foreign banks entering into domestic credit markets. After WTO entry, the Chinese government established the China Banking Regulatory Commission (CBRC) in 2003 to improve asset quality, risk control, and capital adequacy. Consequently, since the CBRC forced all newly founded shareholding commercial banks to have one or more foreign strategic investors, restrictions on foreign investors and banks have relaxed and the number of foreign banks has sharply increased. At the end of 2006, there were 223 foreign banks from 42 countries and 242 representative offices (Wang \& Zhang, 2009).

\subsection{Theoretical Framework on Financial Development and Economic Growth}

The cost of obtaining information or enforcing financial contracts brings the need for financial intermediary development. According to Merton and Bodie (1995), the efficiency of financial intermediaries affects the redistribution of financial resources. When banking sectors' efficiency improves, the cost related to obtaining information and transactions is reduced and credit allocation is more efficient. Similarly, as stock and bond markets mature, people gain more investment opportunities that, in turn, make this investment more liquid than conventional savings. In brief, market frictions due to imperfect credit markets motivate financial intermediary development and, again, these more advanced financial markets improve efficiency that can affect economic growth. According to Levine (2005), a well-developed financial system enables reduction in the cost to produce information, monitor investment activities, manage risk, and to mobilize.

Boyd and Prescott (1986) argued that financial intermediary development reduces the cost for producing information and allocating capital in ways that may improve the allocation of financial resources since people are confronted with the high transaction cost connected with examining firms' and managers' financial soundness. Therefore, the emergence of financial intermediaries that extend loans and accept savings reduce the cost of producing information on possible investment. Greenwood and Jovanovic (1990) suggested a model for the dynamic relationship between finance and economic growth. Like Boyd and Prescott (1986), they agreed that financial intermediary development generates preferable information with the least transaction cost, improves the allocation of financial resources, and, therefore, promotes economic growth. However, unlike Boyd and Prescott (1986), Greenwood and Jovanovic (1990) pointed out that when each investor utilizes financial intermediaries to reduce the cost related to examining the soundness of firms and managers and to investigating economic situations, it is still costly. In their argument, credit accessibility, which is mostly provided by financial intermediaries, is necessary for the implementation of investment activities and business projects. For this reason, as more investors are able to utilize financial services offered by financial intermediaries, the ability of financial intermediaries to produce information on possible investments and to allocate capital will improve.

Lastly, Galor and Zeira (1993) discussed a linear relationship, which implies that a well-developed financial system reduces income inequality. Imperfect financial markets harm economic growth because misallocated credit prevents individuals from investing into human capital. Since the accumulation of human capital is negatively affected by capital market imperfection, the initial wealth distribution has an impact on who has a chance to utilize the credit resources in order to accumulate human capital.

Stiglitz and Weiss (1983) argued that if monitoring investment does not work properly due to an underdeveloped financial system, this imperfect system may impede the mobilization of capital resources from possible investors and savers. Therefore, monitoring investment activities derived from a well-developed financial system affects firms' performance accompanied by large capital investment and, in turn, influences economic growth.

Efficient capital mobilization is necessary for economic growth. As discussed already, one barrier to mobilize 
financial resource is the fixed cost of transaction and information acquisition on possible investments, which can be alleviated by the efficiency of financial intermediaries. Sirri and Tufano (1995) argued that these imperfect market frictions, which cause high transaction and information acquisition costs, can be alleviated by financial intermediaries who provide reliable financial products to investors and savers. Consequently, financial development, which fosters mobilizing financial resources, can stimulate economic growth by boosting capital investment.

In another influential study by Acemoglu and Zilibotti (1997), one advantage of mobilizing financial resources is to create a small denomination investment, which allows individuals to diversify risks, and attract more investment and savings from small investors or savers. As a result, financial development supports the reallocation of existing financial resources and, therefore, gives positive spillover on economic growth.

Aghion et al. (2004) suggested a model to analyze how the ability of companies to access credit affects technological innovation and growth in the long run during recessions. Assuming there exists adjustment costs to research and development $(\mathrm{R} \& \mathrm{D})$, the model incorporates whether companies invest into low return investments or into R\&D, which can enhance companies' growth but might be more risky. Thus, a well-developed financial system enables firms to decrease adjustment costs to $R \& D$, which promotes the ability of firms to access credit for technological innovation, while under-developed financial systems reduces firms' accessibility to credit due to relatively high adjustment costs to R\&D.

Recently, Laeven et al. (2011) suggested a theoretical model reflecting the profit maximization behaviors to explain how financial innovation has been a driving force of financial development and economic growth. In their model, lenders try to screen potential borrowers, companies, and to innovate better ways to screen borrowers. Financial innovation, which creates more effective screening, improves the rate of technological innovation, which affects economic growth. Again, this technological innovation positively affects financial innovation, which is endogenous coevolution of financial and technological innovation.

\subsection{Empirical Evidence on Financial Development and Economic Growth}

The impact of financial intermediary development on economic growth is frequently debated and convincing empirical evidence indicates that financial intermediary development accelerates economic growth. In assessing the impact of financial development on economic growth, some researchers used a pooled cross-country dataset, including developed and developing countries. Joseph Schumpeter (1911) showed that financial services, such as mobilizing savings, evaluating projects, facilitating transactions, monitoring managers, and managing risk, are necessary for economic growth. King and Levine (1993b) investigated Schumpeter's view with a dataset of 80 countries between 1960 and 1989. To measure the degree of financial development, they suggested a ratio of liquid liabilities to GDP, the importance of deposit banks relative to the central bank, the ratio of credit issued to non-financial private firms to total credit, and the ratio of credit issued to nonfinancial private firms to GDP. Their results indicated that a higher degree of financial development is related to greater economic growth, physical capital accumulation, and improvements in economic efficiency. Furthermore, a higher degree of financial development is connected to efficiency improvements and accelerating capital accumulation in the long run.

By means of a cross-country dataset of 63 countries from 1960 to 1995 and dynamic panel techniques, Beck (2000) examined the empirical relationship between financial development and real per capita GDP growth, total factor productivity growth, the accumulation of physical capital, and the rates of private savings, finding that a higher degree of financial development brings about greater economic growth. While previous literature focused on the relationship between financial development and economic growth, Beck also focused on the relation between financial development and the sources of economic growth, such as private savings rates, physical capital accumulation, and total factor productivity. Financial development was positively associated with economic growth and total factor productivity growth and these rigid links do not arise from unobserved country specific effects or endogeneity. However, the relationship between financial development and both physical capital growth and savings are not clear.

In another study, Rioja and Valev (2004) tested whether financial intermediary development affects capital accumulation and productivity using a cross-country dataset of 74 countries and GMM dynamic panel techniques. Three financial development measures were constructed: the ratio of the credit issued to the private sector to the GDP, the ratio of commercial bank assets to commercial plus central bank assets, and the ratio of currency plus demand and interest-bearing liabilities of banks and non-bank financial intermediaries to GDP. Findings revealed that financial development was significantly and positively associated with economic growth, productivity growth, and capital growth. Subsequently, a cross-country dataset of 74 countries was classified into 
low-, middle-, and high-income countries. For middle and high-income countries, the estimated coefficients of each financial development measure were positive and statistically significant at the $1 \%$ level. For low-income countries, however, the estimated coefficients of each financial development measure were not statistically significant. More interestingly, in terms of the coefficient's magnitude, high-income countries' estimated coefficient was larger than that of middle-income countries' estimated coefficient. This implies that the impact of financial development on economic growth varies considerably depending on capital accumulation.

Next, I review literature on whether financial intermediary development affects economic growth in China. The majority of evidence concludes that financial development causes higher economic growth.

Boyreau-Debray (2003) explored the province level relationship between financial intermediation and economic growth in China by applying the traditional growth regression framework to a panel of provinces in China. First, arguing the fragmentation of regional capital markets, the author justified the existence of local credit channels. Next, with 26 Chinese provinces over the period between 1990 to 1999, the author analyzed the impact of financial sector development on economic growth using the GMM system estimator. Credit extended by the financial sector at the province level had a statistically insignificant negative effect on a province's economic growth. In other words, the financial deepening in China did not increase provincial economic growth despite evidence that financial development in China contributed to its national economic performance.

Zhang et al. (2012) assessed even greater fragmentation of financial markets at the city level. Based on a dataset of 286 Chinese cities between 2001 and 2006, Zhang et al. (2012) analyzed the impact of financial development on economic growth by applying traditional first-differenced and system GMM estimators. The Chinese dataset does not allow calculation of traditional indicators of financial development such as the ratio of credits extended by financial intermediaries to private sector to GDP at the city level. Thus, the authors employed the following indicators to measure financial development: 1) the ratio of total loans to GDP to measure financial depth;2) the ratio of total deposits to GDP to capture the size of financial intermediaries; 3) the ratio of total household savings to GDP to measure the degree of household saving mobilization; 4) the ratio of fixed asset investment by domestic loans to investment by state government to capture the substitution of more market and profit oriented financial transactions for state government to allocate capital more efficiently; and 5) the ratio of deposits by firm to total deposits in financial system to measure how financial development contributes to provide banking service to corporations. Their results suggested that financial development has a positive impact on economic growth. In other words, financial deepening, as measured by the size and depth of the financial sector, contributed to Chinese economic growth, and financial development after WTO entry spurred economic growth in China.

However, Law and Singh (2014) found that financial development has a negative impact on economic growth after a certain threshold level. In other words, the relationship between financial development and growth is contingent on the level of financial development, where financial development increases economic growth after a level of financial development surpasses a certain threshold level. They suggested an innovative dynamic panel threshold technique to investigate the association between finance and economic growth based on 87 developed and developing countries over the period between 1980 to 2010. Their empirical findings indicated that the degree of financial development has a positive impact on economic growth only up to a certain threshold. After a certain threshold, further financial development has a negative impact on economic growth.

\section{Financial Development and Inequality}

\subsection{Theoretical Framework on Financial Development and Inequality}

Greenwood and Jovanovic (1990) introduced a non-linear relationship between financial development and inequality, which indicates an inverted U-shaped curve. At the early stage of financial development, due to limited access of credits to poor people, income disparities increase, and then after a certain stage, financial development decreases income disparities. The authors set up a model where financial development can enable people to access the information on risky investment by acquiring and analyzing information so that the development of financial intermediations can contribute to diversify risk of the investment. Moreover, in their model, the cost of joining a financial intermediary is fixed, whereas financial intermediaries take advantage of economies of scale in screening projects. Resource allocation efficiency can be promoted by joining the financial intermediary to stimulate economic growth. In a sense, economic growth occurs when more people are able to access financial intermediaries, allowing them access to higher expected return projects. Under this condition, financial development affects the relationship between growth and income distribution.

The inverted U-shaped hypothesis tells us the following. At low levels of economic development where financial development is less mature in their early developmental stage, fewer people are able to join financial 
intermediaries since the fixed costs to join are high. Thus, economic development is slow and income inequality is quite small. If financial sectors are quite well developed (more developed than at the early stage) in the middle of the developmental stage, economic growth is faster and income inequality increases more than the early stage of financial development. Lastly, if financial development is fully mature at the maturity level, income inequality will decrease again because more people can enjoy the full range of benefits from a formal financial system and be quite stable at the end. In summary, based on the inverted U-shaped hypothesis suggested by Greenwood and Jovanovic (1990), at the early stage of economic development, financial development increases income inequality. However, as the country reaches a stage where more low-income people have easier access to credit, income inequality will decrease.

Liang's (2006) empirical analysis provides strong evidence to the linear hypothesis (Banerjee \& Newman, 1993; Galor \& Zeira, 1993). The theoretical model by Galor and Zeira (1993) studied the relationship between income distribution and macroeconomics by investment in human capital. Under the assumption that the credit market is imperfect, the wealth distribution affects aggregate output and investment activities in human capital in the short run. For this result to be effective in the long run as well, the authors added an element of non-convexity to their theoretical model, which refers to indivisibility in investment in human capital. When credit markets are imperfect and a fixed cost connected with schooling is high, only rich dynasties are able to invest in their human capital. Thus, an imperfect financial market system hinders the poor from accumulating human capital.

In the face of a credit market's imperfections and indivisibilities in investment in human capital, the wealth distribution in conjunction with financial market imperfection influences aggregate levels of human capital and aggregate output level. If wealth distribution is not quite equal, fewer individuals accumulate human capital so that it will decrease aggregate efficiency and, thus, economic growth. In the existence of financial market imperfections, economic growth in the long run and the persistence of inequality depends on the initial wealth distribution. The theoretical model by Galor and Zeira (1993) shows that credit accessibility will increase as a financial market develops. As more low-income people are able to borrow money to invest in their human capital, economic growth increases, and inequality is reduced.

As a recent theoretical work on financial development and inequality, Bumann and Lensink (2016) developed a tractable model that portrays the relationship between agents having different investment abilities and banking sectors. As two possible interventions which liberalize the banking sector, this tractable model introduces an increase in the size of foreign investments and a decrease in reserve requirements, which can be utilized to raise domestic loans. The efficiency of banking sector and the adjustments of interest rates, which influence agents with varying investment abilities, can be improved by financial liberalization or financial depth. Their tractable model suggests that financial liberalization will decrease income disparities when financial depth is high.

\subsection{Empirical Evidence on Financial Development and Inequality}

As discussed above, theoretical models for the linear and inverted U-shaped hypotheses have distinct predictions for the link between financial development and income inequality. Clarke et al. (2003) explored the relationship between financial development and income inequality using a dataset of 91 countries over the period between 1960 to 1995. They found strong support for an inverse linear association between financial development and income inequality, which is the linear hypothesis suggested by Banerjee and Newman (1993) and Galor and Zeira (1993). They did not support the inverted-U shaped hypothesis since the coefficients of the squared term for the financial development measures were not statistically significant. Incidentally, their main findings provide some supportive evidence for an augmented Kuznets hypothesis, where the industrial structure (industrial, agricultural, service sectors) is necessary to explain the association between economic development and income inequality. The authors' conclusion was that financial development may decrease income inequality since the coefficients of financial development indicators were negative and statistically significant.

Wei and $\mathrm{Wu}$ (2001) studied the association between urban-rural income inequality and the degree of openness in trade using 100 Chinese cities over the period between 1988 to 1993 . The authors constructed an urban-rural income ratio to measure income disparity between urban and rural areas and used a ratio of total export to GDP to measure the degree of openness at the city level rather than the aggregate of urban and rural due to data limitation. The empirical findings suggested that Chinese cities having a higher ratio of trade to the GDP tended to reduce the urban-rural income disparity.

Next, domestic income disparity in China, which differs from a cross-country analysis of income disparity, is discussed. Tsui (1993) decomposed Chinese regional disparities into five different categories: within-province level, inter-province level, within rural level, urban and rural, and within-urban inequality. Based on 2306 counties and cities in 1982, the author used gross value of industrial and agricultural outputs, infant mortality 
rate, and illiteracy rate to capture various aspects of regional disparities. The findings indicate that the inequality of within-province level is dominant sources of regional inequalities.

Liang (2006) tested the two theoretical hypotheses on the link between the financial development and income inequality based on the system GMM estimator. Empirical results support the linear hypothesis that the development of the financial sector decreases urban income inequality. All measures of financial development were significant with the expected signs. After adding the squared terms of the financial variables into the model to test the inverted U-shaped hypothesis, the financial measures were not statistically significant, which does not support the inverted U-shaped hypothesis by Greenwood and Jovanovic. In conclusion, after the Chinese government launched radical urban reforms, the development in the financial sector triggered a decrease in income inequality.

According to Liang (2006), financial development significantly reduced income inequality in China. However, it is still controversial whether financial development helps to decrease income disparity in China. First of all, many significant reforms and institutional innovations in the financial sector occurred between 1995 and 2010 . The Chinese financial system solidified after the Chinese government announced the Central Bank Law and the Commercial Bank Law in 1995. Large money injections occurred in 1998 to relieve the heavy debt of four major state-owned banks and in 2003 to restructure state-owned banks to joint-stock commercial banks with stock market public listings. When China joined the WTO, its banking system was required to be fully open to foreign competitors by 2006. Therefore, we need to investigate the recent Chinese data covering the late 1990s and early 2000s to the present, which captures an important moment in Chinese banking sectors' reform after WTO entry.

$\mathrm{Li}$, Squire, and Zou (1998) found that cross-country variations of inequalities were significantly larger than within-country variations of inequalities. They used a dataset on Gini coefficients of 2,480 observations covering 112 developed and developing countries from 1947 to 1994 . They also examined the determinants of income inequality, looking at policies that are beneficial to the rich but may not be favorable to the poor, and imperfections in credit markets. The authors adjusted the data to achieve a more balanced panel dataset and observed that well-equipped financial markets reduce income disparity.

Similarly, Beck, Demirgüç-Kunt, and Levine (2004) examined that well-developed financial sectors decrease poverty. They first tested whether a developed financial system influences the income of each economy's poorest $20 \%$. Second, the authors investigated the association between financial development and changes in income distribution. Lastly, they introduced direct measures of poverty alleviation (the growth rate of the fraction of the population living under $\$ 1$ per day), testing whether the developed financial system affects poverty alleviation positively or negatively. Using an 82-cross-country sample over the period between 1960 to 1999, they discovered that a developed financial system decreases income inequality after controlling for real GDP growth per capita. Second, a developed financial system decreases the percentage of the population living on less than $\$ 1$ a day, suggesting that a developed financial system alleviates the poverty rate. Unlike the previous research above, the main contribution of the paper by Beck, Demirgüç-Kunt, and Levine (2004) was the examination of the aggregate relationship between financial development and both income disparity and the decrease in poverty. However, its limitation was that private credit, a commonly used indicator for financial development, was the only available measure of financial development since other traditional indicators were not available across countries. In this light, Wei and Wu (2001) and Atkinson and Brandolini (2001) argued that cross-country analyses on income disparity are less credible due to the lack of data and processing methodology.

Whether financial development increases or decreases income inequality is still ambiguous. The following literature unquestionably illustrates that Chinese economic transition and financial development is urban-centered and urban-favored, consequently deepening the income gap between urban and rural areas. Chinese economic transition, especially in the financial market condition, is very much associated with changes in urban income distribution. For example, according to Wei and Wang (1997) and Zhang et al. (2003), since a well-equipped financial system played a pivotal role in the process of reforming the Chinese economy and restructuring state owned firms, urban-oriented developments in the banking sector are inevitable.

Wei and Wang (1997) examined the link between state-owned banks (SOBs) and state-owned manufacturing enterprises (SOEs) using 370 Chinese cities for 1986, 1989, 1990, and 1991 provided by the Urban Statistical Yearbook of China. First, they used a simple regression model to examine whether the effectiveness of fiscal and other economic reforms are negatively correlated with the degree of SOBs' lending bias toward SOEs. They found that loans from the Chinese banking sector are biased in favor of SOEs. Chinese cities with a higher share of SOEs in industrial output are more likely to have greater volume of loans after controlling for city size, capital intensity, and the ratio of loan to output. 
In another example of financial development associated with changes in urban-rural income distribution, Qi et al. (2003) discussed the impact of financial development on urban and rural income disparity using a panel dataset of Chinese 28 provinces over the period between 1978 to 1998 . The authors used the ratio of urban to rural per capita net income as the dependent variable and used the ratio of total loans to provincial GDP as an indicator of financial development. Controlling for the infrastructure in each province, institutional reforms in rural areas, and the degree of international integration, they discovered that as the ratio of total loans to provincial GDP increased, the income gap between urban and rural areas in China widened significantly. They argued that urban-favored regulations and interventions on the rural economy caused urban bias of credit allocation in China's financial development. This finding clearly indicates that financial development in China increases income disparity.

Recently, Furceri and Loungani (2015) investigated the relationship between financial depth and income inequality based on cross-country dataset for 149 countries between 1970 and 2010. The authors found that financial depth measured by capital account liberalization increases income inequality in countries where the level of financial development is low. Likewise, $\mathrm{Li}$ and $\mathrm{Yu}$ (2014) found that financial deepening measured by the ratio of credit to GDP increases income inequality based on panel data for 18 Asian countries from 1996 and 2005. In addition, Denk and Cournede (2015) argued that the size of finance measured by intermediated credit and stock market capitalization has a positively significant impact on income inequality in the sample data of 33 OECD countries. Moreover, recent literature (Jauch \& Watzka, 2016) found positive impact of financial development, which is measured by credit to GDP, on income inequality, which is measured by the Gini coefficient. Their analysis was based on an unbalanced dataset of 138 developed and developing countries between 1960 and 2008. After controlling for GDP per capita and country fixed effects, their empirical findings reject theoretical models suggesting a negative impact of financial development on income disparities, and their results are consistent with the alternative specifications with different indicators of financial development.

In contrast, Bumann and Lensink (2016) discussed theoretical and empirical relationships between financial liberalization and income inequality. The theoretical model set up by the authors suggests that financial liberalization increases the efficiency of banking sectors and adjusts interest rates, which influence investors and savers' income and, therefore, leads to a reduction in income inequality. Their empirical results indicate that financial liberalization measured only by capital account liberalization decreases income inequality in countries where financial depth measured by the ratio of private credit to GDP is more than $25 \%$.

\section{Conclusion}

Theoretically, financial development enhances economic development since well-developed financial intermediaries trigger investments and savings. This is because well-developed financial systems decrease the cost of transaction and producing information, improve monitoring investment activities, enable individuals to diversify possible risk from their investments, and help to mobilize investment and savings, which is required for economic growth. Existing empirical evidence supports these claims. Furthermore, most empirical research in China also supports the hypothesis that financial development has a positive impact on economic growth.

However, it is still unclear whether financial intermediary development reduces income inequality, although it is quite evident that financial development stimulates the rate of economic growth. In general, theoretically and empirically, financial development provides more economic opportunities, which reduces income disparities and the number of people living below the poverty line. Yet, some cross-sectional analyses indicate that the effects of financial development on economic growth or income inequality differ by income level of the country.

Another important issue is policies. Little research exists on the trend of income inequality with financial sector policies implemented after entrance into the WTO. More work on the relationship between financial policies and the pattern of income inequality is needed for economies at different stages of economic development. In particular, the Chinese government has actively adopted several financial policies such as liberalization of the interest rate, relaxation of regulation on foreign banks, and mitigation of restrictions on ownership takeovers, after joining the WTO in 2001. China's policy implementations are very unique, making it difficult to generalize previous literature. Thus, in the Chinese case, more empirical work on the association between financial policies and the trend of income inequality is needed, especially in the time period after joining the WTO.

Lastly, an important reform policy was the designation of special economic zones in the coastal area to draw foreign direct investments and international trade. As China's economic reforms progress, the coastal provinces are far ahead of the inland provinces with respect to the accumulation of human capital and infrastructure facilities. Therefore, the developmental gap between the coastal and inland provinces has widened. In 2011, the average annual income from Eastern provinces was 82,128 (Yuan), while those from Central and Western 
provinces were 34,134 (Yuan) and 31,854 (Yuan), respectively. Future research should explore the spatial association between financial development and income inequality. This will complement the existing body of studies by considering the spatial autocorrelation of errors and spatial lag dependences in the association between financial development and income inequality in China.

Research on the interactions between economic growth, financial development, and income inequality assists policy makers in shaping future policy. Future studies need to consider their dynamic interactions, especially for countries that are facing or undergoing financial system reform, such as China.

\section{References}

Acemoglu, D., \& Zilibotti, F. (1997). Was Prometheus Unbound By Chance? Risk, Diversification, and Growth. Journal of Political Economy, 105, 709-775. https://doi.org/10.1086/262091

Aghion, P., Angeletos, M., Banerjee, A., \& Manova, K. (2004). Volatility and Growth: The Role of Financial Development. Mimeo, Department of Economics, Harvard University.

Allen, F., Qian, J., \& Qian, M. (2005). Law, Finance and Economic Growth in China. Journal of Financial Economics, 77(1), 57-116. https://doi.org/10.1016/j.jfineco.2004.06.010

Atkinson, A. B., \& Brandolini, A. (2001). Promise and Pitfalls in the Use of 'Secondary' Data Sets: Income Inequality in OECD Countries As a Case Study. Journal of Economic Literature, 39(3). https://doi.org/10.1257/jel.39.3.771

Banerjee, A. V., \& Newman, A. F. (1993). Occupational Choice and the Process of Development. Journal of Political Economy, 101, 274-298. https://doi.org/10.1086/261876

Barrios, S., \& Strobl, E. (2009). The dynamics of regional inequalities. Regional Science and Urban Economics, 39(5), 575-591. https://doi.org/10.1016/j.regsciurbeco.2009.03.008

Beck, T., Demirgüç-Kunt, A., \& Levine, R. (2004). Finance, Inequality and Poverty: Cross-Country Evidence. World Bank Policy Research Working Paper, 3338, World Bank, Washington D.C. https://doi.org/10.3386/w10979

Beck, T., Levine, R., \& Loayza, N. (2000). Finance and the sources of growth. Journal of Financial Economics, 58(1-2), 261-300. https://doi.org/10.1016/S0304-405X(00)00072-6

Berger, A. N., Hasan, I., \& Zhou, M. (2009). Bank ownership and efficiency in China: What will happen in the world's largest nation? Journal of Banking and Finance, 33(1), 113-130. https://doi.org/10.1016/j.jbankfin.2007.05.016

Boyd, J. H., \& Prescott, E. C. (1986). Financial intermediary-coalitions. Journal of Economics Theory, 38, 211-232. https://doi.org/10.1016/0022-0531(86)90115-8

Boyreau-Debray, G. (2003). Financial Intermediation and Growth: Chinese Style. World Bank Policy Research Working Paper, 3027. https://doi.org/10.1596/1813-9450-3027

Brandt, L., \& Zhu, X. (2000). Redistribution in a Decentralized Economy: Growth and Inflation in China under Reform. Journal of Political Economy, 108(2). https://doi.org/10.1086/262124

Bumann, S., \& Lensink, R. (2016). Capital account liberalization and income inequality. Journal of International Money and Finance, 61, 143-162. https://doi.org/10.1016/j.jimonfin.2015.10.004

Calomiris, C. W., \& Hubbard, R. G. (1990). Firm Heterogeneity, Internal Finance, and Credit Rationing. Economic Journal, Royal Economic Society, 100(399), 90-104. https://doi.org/10.2307/2233596

Chen, J., \& Fleisher, B. M. (1996). Regional Income Inequality and Economic Growth in China. The Journal of Comparative Economics, 22, 141-164. https://doi.org/10.1006/jcec.1996.0015

Clarke, G., Xu, L. C., \& Zou, H. F. (2003). Finance and Income Inequality: Test of Alternative Theories. World Bank Policy Research Working Paper, 2984, World Bank, Washington D.C. https://doi.org/10.2139/ssrn.364160

Cull, R., \& Xu, L. C. (2000). Bureaucrats, State Banks, and the Efficiency of Credit Allocation: The Experience of Chinese State-Owned Enterprises. Journal of Comparative Economics, 28(1), 1-31. https://doi.org/10.1006/jcec.1999.1642

Cull, R., \& Xu, L. C. (2003). Who gets credit? The behavior of bureaucrats and state banks in allocating credit to Chinese state-owned enterprises. Journal of Development Economics, 71(2), 533-559. https://doi.org/10.1016/S0304-3878(03)00039-7 
Denk, O., \& Cournede, B. (2015). Finance and Income Inequality in OECD countries. OECD Economics Department Working Paper 1224, OECD Publishing Paris. https://doi.org/10.2139/ssrn.2649944

Devereux, M. B., \& Smith, G. W. (1994). International Risk Sharing and Economic Growth. International Economic Review, 35, 535-550. https://doi.org/10.2307/2527072

Fawaz, F., Rahnama, M., \& Valcarcel, V. J. (2014). A Refinement of the Relationship between Economic Growth $\begin{array}{llll}\text { and Income Inequality, Applied } & \text { Economics, 46(27), 3351-3361. }\end{array}$ https://doi.org/10.1080/00036846.2014.929624

Ferri, G. (2009). Are New Tigers Supplanting Old Mammoths in China's Banking System? Evidence from a sample of city commercial banks. Journal of Banking \& Finance, 33(1), 131-140. https://doi.org/10.1016/j.jbankfin.2007.06.013

Furceri, D., \& Loungani, P. (2015). Capital Account Liberalization and Inequality, IMF, Washington DC, Working Paper 15/243. https://doi.org/10.5089/9781513531083.001

Galor, O., \& Zeira, J. (1993). Income Distribution and Macroeconomics, Review of Economic Studies, 60, 35-52. https://doi.org/10.2307/2297811

Goldsmith, R. W. (1969). Financial Structure and Development. New Haven, CT: Yale University Press.

Greenwood, J., \& Jovanovic, B. (1990). Financial Development, Growth, and the Distribution of Income. Journal of Political Economy, 98, 1076-1107. https://doi.org/10.1086/261720

Jauch, S., \& Watzka, S. (2016). Financial Development and Income Inequality: A Panel Data. Empirical Economics, 51(1), 291-314. https://doi.org/10.1007/s00181-015-1008-x

King, R. G., \& Levine, R. (1993b). Finance and Growth: Schumpeter might be right, Quarterly Journal of Economics, 108(3), 717-737. https://doi.org/10.2307/2118406

Krongkaew, M., \& Kakwani, N. (2003). The Growth-Equity Trade-off in Modern Economic Development: The Case of Thailand. Journal of Asian Economics, 14, 735-757. https://doi.org/10.1016/j.asieco.2003.10.003

Kuznets, S. (1955). Economic Growth and Income Inequality. The American Economic Review, 45, 1-28.

Laeven, L., Levine, R., \& Michalopoulos, S. (2011). Financial innovation and endogenous growth. Journal of Financial Intermediation, 24(1), 1-24. https://doi.org/10.1016/j.jfi.2014.04.001

Lardy, N. R. (1978). Economic Growth and Distribution in China. New York: Cambridge Univ. Press. https://doi.org/10.1017/CBO9780511528262

Lardy, N. R. (1980). Regional Growth and Income Distribution in China. In R. F. Dernberger (Ed.), China's Development Experience in Comparative Perspective (pp. 153-190). Cambridge, MA: Cambridge Univ. Press. https://doi.org/10.4159/harvard.9780674367388.c8

Law, S. H., \& Singh, N. (2014). Does too Much Finance Harm Economic Growth? Journal of Banking \& Finance, 41, 36-44. https://doi.org/10.1016/j.jbankfin.2013.12.020

Levine, R. (1997). Financial Development and Economic Growth: Views and Agenda. Journal of Economic Literature, 35, 688-726.

Levine, R. (2005). Finance and Growth: Theory and evidence. Handbook of Economic Growth, 1(12), 865-934. https://doi.org/10.1016/S1574-0684(05)01012-9

Li, H., Squire, L., \& Zou, H. F. (1998). Explaining International and Intertemporal Variations in Income Inequality. The Economic Journal, 108, 26-43. https://doi.org/10.1111/1468-0297.00271

Li, J., \& Yu, H. (2014). Income Inequality and Financial Reform in Asia: The Role of Human Capital. Applied Economics, 46, 2920-2935. https://doi.org/10.1080/00036846.2014.916390

Liang, Z. (2006). Financial Development and Income Distribution: A System GMM Panel Analysis with Application to Urban China. Journal of Economic Development, 31(2), 1-21.

Lucas Jr., R. E. (1988). On the Mechanics of Economic Development. Journal of Monetary Economics, 22, 3-42. https://doi.org/10.1016/0304-3932(88)90168-7

Lyons, T. P. (1992). Interprovincial Disparities in China: Output and Consumption, 1952-1987. Economic Development Cultural Change, 39(3), 471-506. https://doi.org/10.1086/451887

Merton, R. C., \& Bodie, Z. (1995). A Conceptual Framework for Analyzing the Financial Environment. In D. B. Crane et al. (Eds.), The Global Financial System: A Functional Perspective (pp. 3-31). Boston, MA: 
Harvard Business School Press.

Naughton, B. et al. (2008). A Political Economy of China's Economic Transition China's Great Transformation. In B. Loren, \& R. G. Thomas (Eds.), China's Great Transformation. Cambridge: Cambridge University Press.

Obstfeld, M. (1994). Risk-taking, Global Diversification, and Growth. American Economic Review, 84, 1310-1329.

Oi, J. C. (1993). Reform and Urban Bias in China. The Journal of Development Studies, 29(4), 129-148. https://doi.org/10.1080/00220389308422297

Oshima, H. T. (1992). Kuznets' Curve and Asian Distribution Trends. Hitotsubashi Journal of Economics, 33(1), 95-111.

Patrick, H. (1966). Financial Development and Economic Growth in Underdeveloped Countries. Economic Development Cultural Change, 14, 174-189. https://doi.org/10.1086/450153

Psacharopoulos, G., Morley, S., Fiszbein, A., Lee, H., \& Wood, W. C. (1995). Poverty and Income Inequality in Latin America. Review of Income and Wealth, 41(3), 245-264. https://doi.org/10.1111/j.1475-4991.1995.tb00119.x

Qi, Z., Ran, T., Mingxing, L., \& Yiu Por Chen, V. (2003). Financial Development and Urban-Rural Income Disparity in China. Paper presented at the Chinese Economist Society 2003 annual meeting on Chinese Economy After WTO: Opportunities and Challenges of Globalization, August, Ann Arbor, Michigan.

Rawski, G. et al. (2008). China's Industrial Development, in Brandt and Rawski. China's Great Transformation. Cambridge: Cambridge University Press.

Rioja, F., \& Valev, N. (2004a). Finance and the sources of growth at various stages of economic development. Economic Inquiry, 42(1), 127-140. https://doi.org/10.1093/ei/cbh049

Scully, G. W. (2002). Economic Freedom, Government Policy and the Trade-off between Equity and Economic Growth, Public Choice, 113, 77-96. https://doi.org/10.1023/A:1020308831424

Sirri, E. R., \& Tufano, P. (1995). The economics of pooling. In D. B. Crane et al. (Eds.), The Global Financial System: A Functional Approach (pp. 81-128). Harvard Business School Press, Boston, MA.

Stiglitz, J., \& Weiss, A. (1983). Incentive effects of terminations: Applications to credit and labor markets. American Economic Review, 7(5), 912-927.

Tsui, K. Y. (1993). Decomposition of China's Regional Inequalities, Journal of Comparative Economics, 17, 600-627. https://doi.org/10.1006/jcec.1993.1045

Turnovsky, S. J. (2015). Economic growth and inequality: The role of public investment. Journal of Economic Dynamics and Control, 61, 204-221. https://doi.org/10.1016/j.jedc.2015.09.009

Vijverberg, C-P. C. (1991). Equity and Growth. Southern Economic Journal, 57(3), 798-810. https://doi.org/10.2307/1059792

Vijverberg, C-P. C. (1996). Macroeconomic Conditions, Class Mobility, and Inequality. Journal of Macroeconomics, 18(2), 315-340. https://doi.org/10.1016/S0164-0704(96)80072-3

Wang, S. and Zhang, J. (2009). Location Strategies under Risk and Asymmetric Information, with an Application to Multinational Banking. Working Paper.

Wei, S. J., \& Wang, T. (1997). The Siamese Twins: Do State-owned Banks Favor State-owned Enterprises in China? China Economic Review, 8, 19-29. https://doi.org/10.1016/S1043-951X(97)90010-9

Wei, S. J., \& Wu, Y. (2001). Globalization and Inequality: Evidence from Within China. NBER Working Paper Series, No. 8611. https://doi.org/10.3386/w8611

Williamson, J. G. (1965). Regional Inequality in the Process of National Development. Economic Development and Cultural Change, 17(4 pt. 2), 3-84. https://doi.org/10.1086/450136

Xie, Y., \& Zhou, X. (2014). Income Inequality in Today's China. Proceedings of the National Academy of Sciences, 111(19), 6928-6933. https://doi.org/10.1073/pnas.1403158111

Yang, D. L., \& Wei, H. (1996). Rural Enterprise Development and Regional Policy in China. Asian Perspective, 35,1 .

Zhang, J., Wang, L., \& Wang, S. (2012). Financial development and economic growth: Recent evidence from 
China. Journal of Comparative Economics, 40, 393-412. https://doi.org/10.1016/j.jce.2012.01.001

\section{Notes}

Note 1. Source: OECD, "Income Distribution and Poverty: By country" archived from the original on 2015-04-02.

Note 2. Source: China Banking Regulatory Commission (CBRC)'s Annual Report.

Note 3. The concept of G-2 (Group of Two) was proposed by noted economist C. Fred Bergsten in 2005.

Note 4. The Agricultural Development Bank of China (ADBC), China Development Bank (CDB), and the Export-Import Bank of China (Chexim) were found in 1994 as policy banks to conduct government expenditure. Brandt and Zhu (2000) indicated that 84 percent of all new credits extended by state owned banks was utilized for state owned enterprises from 1979 to 1993 . This is called policy loans.

\section{Copyrights}

Copyright for this article is retained by the author(s), with first publication rights granted to the journal.

This is an open-access article distributed under the terms and conditions of the Creative Commons Attribution license (http://creativecommons.org/licenses/by/4.0/). 